\title{
Pengembangan Kurikulum Pembelajaran Bahasa Arab di Masa Pandemi Covid-19
}

\author{
Ayu Desrani ${ }^{1}$, Dzaki Aflah Zamani ${ }^{2}$ \\ Sekolah Tinggi Agama Islam Al-Musdariyah Cimahi, Indonesia ${ }^{1}$, \\ Universitas Darussalam Gontor, Indonesia ${ }^{2}$ \\ aydesrani@gmail.com ${ }^{1}$,dzakizamani123@gmail.com ${ }^{2}$
}

\begin{abstract}
:
Purpose- this study aims tofind out and analyze the appropriate curriculum in Arabic learning during the covid-19 pandemic, where at this time the covid-19 pandemic is increasing and its spread is growing rapidly, so it becomes a challenge for a teacher to overcome the learning so that it continues as it should. , including learning Arabic.
\end{abstract}

Design/Methodology/Approach- This study used a qualitative approach with a library research method that used books and other literatures as the main object. This research was analyzed descriptively on the content to provide a clear, objective, systematic, analytical and critical description and description of the appropriate Arabic language learning curriculum during the COVID-19 pandemic.

Findings- 4 basics in the development of the Arabic language learning curriculum during the pandemic: 1) the preparation of learning objectives must be adapted to the circumstances of students and socialized to parents to work together to achieve these goals. 2) the content or material content is designed in such a way as to get students to lead to higher order thinking skills. 3) During the learning process the teacher is required to be as creative as possible to guide learning, the use of appropriate methods and media is very influential. 4) evaluation based on project is highly recommended to avoid the possibility of students cheating on each other.

Research Limitation/Implications- This study cannot cover all in detail about Arabic language skills, because in essence during the current COVID-19 pandemic, teachers need more ways in which subject matter can be conveyed properly to students. However, this study can provide a comprehensive picture of the needs of Arabic language teachers in teaching, one of which is the use of learning technology.

Keywords: Curriculum, Learning Arabic, Covid-19

\begin{abstract}
Abstrak:
Tujuan- penelitian ini bertujuan untuk mengetahui dan menganalisis kurikulum yang cocok dalam pembelajaran bahasa arab pada masa pandemi covid-19, dimana pada saat ini pandemi covid-19 semakin bertambah dan penyebarannya berkembang pesat, sehingga menjadi tantangan seorang guru untuk mengatasi pembelajaran tersebut agar tetap berlangsung sebagaimana mestinya, tidak terkecuali pembelajaran bahasa arab.
\end{abstract}

Desain/Metodologi/Pendekatan- Penelitian ini menggunakan pendekatan kualitatif dengan metode studi pustaka (library research) yang menggunakan buku-buku dan literarur-literatur lainnya sebagai objek utama. Penelitian ini dianalisis secara deskriptif terhadap konten untuk memberikan gambaran dan keterangan secara jelas, objektif, sistematis, analitis dan kritis mengenai kurikulum pembelajaran bahasa arab yang sesuai pada masa pandemi COVID-19

Temuan- 4 dasar dalam pengembangan kurikulum pembelajaran bahasa arab pada masa pandemi: 1) penyusunan tujuan pembelajaran harus disesuaikan dengan keadaan peserta didik dan disosialisasikan kepada orang tua untuk bekerja sama 
mencapai tujuan tersebut. 2) konten atau isi materi dirancang sedemikian rupa untuk sampai kepada siswa arahkan pada keterampilan berpikir tingkat tinggi. 3) selama proses pembelajaran guru dituntut sekreatif mungkin untuk menuntun pembelajaran penggunaan metode dan media yang tepat sangat berpengaruh. 4) evaluasi sangat disarankan berbasis project untuk menghindari kemungkinan siswa dalam menyontek satu sama lain.

Batasan Penelitian/Implikasi - penelitian ini tidak dapat mencakup keseluruhan secara mendetail tentang keterampilan-keterampilan bahasa arab, karena pada hakikatnya pada masa pandemi-covid 19 saat ini guru lebih membutuhkan cara bagaimana agar materi pelajaran dapat tersampaikan dengan baik kepada peserta didik. Namun demikian penelitian ini dapat memberikan gambaran secara menyeluruh terhadap kebutuhan guru bahasa arab dalam mengajar, salah satunya penggunaan teknologi belajar.

Kata Kunci: Kurikulum, Pembelajaran Bahasa Arab, Covid-19

\section{PENDAHULUAN}

Pada masa pandemi covid-19 pendidikan mengalami masalah sangat serius. Untuk mengatasi masalah tersebut kementerian pendidikan dan kebudayaan (Kemendikbud) menerbitkan pedoman pelaksanaan kurikulum pada satuan pendidikan dalam kondisi khusus. Satuan pendidikan dalam kondisi khusus dapat menggunakan kurikulum yang sesuai dengan kebutuhan pembelajaran peserta didik. Satuan pendidikan pada kondisi khusus dalam pelaksanaan pembelajaran dapat tetap mengacu pada kurikulum nasional atau menggunakan kurikulum darurat dan melakukan penyederhanaan kurikulum secara mandiri. Semua jenjang pendidikan dapat memilih dan menentukan kurikulumnya sendiri pada kondisi khusus. ${ }^{1}$

Pembelajaran dalam jaringan (daring) atau pembelajaran jarak jauh (PJJ) merupakan opsi utama bagi para pendidik ketika ada instruksi langsung dari pemerintah pusat untuk mengantisipasi penyebaran wabah virus corona atau biasa disebut Coronavirus Disease 2019 (covid-19).² Sehingga pembelajaran daring menekankan pada pembelajaran mandiri (self study), dan menggunakan teknik-teknik khusus dalam mendesain materi pembelajaran seperti penataan organisasi, administrasi dan metodologi khusus komunikasi melalui berbagai media

\footnotetext{
${ }^{1}$ Kemendikbud GTK, "Kebijakan Kemendikbud Di Masa Pandemi," Https://Gtk.Kemdikbud.Go.Id/.

2 Dian Ratu Ayu Uswatun Khasanah, Hascaryo Pramudibyanto, and Barokah Widuroyekti, "Pendidikan Dalam Masa Pandemi Covid-19," Jurnal Sinestesia (2020).
} 
seperti komputer, televisi, radio, telepon, internet, video dan sebagainya semuanya mencakup dalam kurikulum pembelajaran. ${ }^{3}$

Guru dapat memilih kurikulum pendidikannya sendiri. akan tetapi tetap memperhatikan kondisi pada masa pandemi covid-19. Artinya jika dia tetap mengacu pada kurikulum nasional tetap harus disesuaikan dengan keadaan saat ini. ${ }^{4}$ Hal ini sesuai dengan pendapat Donald E. Orlasky mengatakan bahwa kurikulum tetap direncana atau di programkan sesuai dengan pengalaman peserta didik dan tetap dikembangkan oleh sekolah sesuai dengan kondisi peserta didik dan sekolah. ${ }^{5}$

Terkait dengan bagaimana orang menilai belajar bahasa Arab, banyak sudut pandang yang heterogen. Sebagian ada yang memandang bahasa Arab adalah bahasa agama, karena bahasa Arab dipandang sebagai alat untuk mempelajari dan memahami teks-teks yang berbahasa Arab. ${ }^{6}$ Ada juga yang berpendapat bahwa belajar bahasa Arab adalah belajar bahasa ilmu pengetahuan Islam. Pandangan ini juga tidak salah, karena memang ilmu-ilmu Islam mayoritas referensinya berbahasa Arab. Ada pula yang berpandangan bahwa belajar bahasa Arab adalah belajar berbahasa. ${ }^{7}$ Pandangan ini lebih menitik beratkan pada bagaimana orang belajar bahasa Arab sebagai bahasa komunikasi sehari-hari. Perbedaan sudut pandang ini, menyebabkan adanya perbedaan metode, strategi, teknik, bahan ajar, media pembelajaran dan evaluasi pembelajaran bahasa Arab. Apabila belajar bahasa Arab tujuannya agar peserta didik dapat berkomunikasi atau bahasa Arab sebagai alat komunikasi, maka belajar bahasa Arab lebih menitik beratkan pada kosa kata dan praktik berbicara dengan menggunakan bahasa Arab. ${ }^{8}$

Terlepas dari berbagai sudut pandang tersebut, jika kita amati dengan seksama, maka pembelajaran bahasa Arab banyak menemui berbagai kendala dan

\footnotetext{
${ }^{3}$ Sri Winarni and Syahrial, "Inovasi Kurikulum Dan Pembelajaran Pada Masa Pandemi Civid-19," Jurnal Ilmiah Wahana Pendidikan https://jurnal.unibrah.ac.id/index.php/JIWP (2020).

${ }^{4}$ pengelola web Kemdikbud, "Kemendikbud Terbitkan Pedoman Penyelenggaraan Belajar Dari Rumah," Jakarta, 28 Mei 2020.

${ }^{5}$ Donald E. Orlosky, Curriculum Development Issues and Insights (Rand Mcnally Education Series) (chicago: rand mcnally, 1978), 16.

${ }^{6}$ Nanang Kosim et al., "Pembelajaran Bahasa Arab Melalui Daring; Problematika, Solusi Dan Harapan," Journal of Food System Research 2, no. 2 (1995): 54-65, https://doi.org/10.5874/jfsr.2.2_54.

${ }^{7}$ Ahmad Taufik, "Strategi Pembelajaran Bahasa Arab Berbasis Internet," SELL Journal 5, no. 1 (2020): 55 .

${ }^{8}$ Nabila Nurbati Zulaini et al., "Learning Arabic for Elementary Schools During the Covid-19 Outbreak," Al-Mudarris 3, no. 1 (2020).
} 
hambatan. Di tengah kondisi Covid-19 ini pembelajaran bahasa Arab tidak bisa dilaksanakan secara tatap muka di kelas. Kondisi tersebut menuntut lembaga pendidikan untuk melakukan inovasi dalam proses pembelajaran. Pembelajaran melalui daring (dalam jaringan) merupakan salah satu alternatif yang diterapkan dalam pembelajaran bahasa Arab. Dalam pelaksanaannya pembelajaran bahasa Arab melalui daring ini menemui berbagai kendala. ${ }^{9}$

Penelitian terdahulu terkait pembelajaran bahasa arab pada masa pandemi covid-19 ini telah diteliti oleh beberapa peneliti. Beberapa penelitian terdahulu dan baru-baru ini masih mengkaji tentang problematika pembelajaran bahasa Arab, dan mengatakan probelmatika yang dihadapi dalam pembelajaran bahasa arab terdiri dari problematika bersumber dari kebahasaan atau linguistik, seperti tata bunyi, kosa kata, tata kalimat, tulisan dan gramatikal, dan problematika non-linguistik seperti buku ajar, metode belajar, sarana dan prasarana belajar, minat dan motivasi belajar.1011 Serta penelitian Didin Jamaluddin dkk dalam penelitian mereka menyebutkan pembelajaran daring pada pandemi ini dapat dijadikan pengalaman tambahan bagi mahasiswa, siswa dan guru di masa depan atau kemudian hari. ${ }^{12}$ Menurut Ahmadi dkk dengan adanya hambatan pada proses pembelajaran dapat mempengaruhi motivasi dan minat belajar itu sendiri kepada siswa sehingga perlu solusi dan proyeksi dari hambatan tersebut. ${ }^{13}$

Terkait dengan hal tersebut, kurikulum pembelajaran dirancang sedemikian rupa untuk mengatasi pembelajaran daring. Apabila kita melihat atau mengaitkan dengan kurikulum yang diresmikan oleh kementerian agama dalam KMA No 183 tahun 2019 tentang kurikulum pembelajaran PAI dan Bahasa Arab yang diterapkan secara bertahap pada tahun ajaran 2020/2021, hal tersebut sangat cocok untuk kita gunakan dalam pembelajaran saat ini. Yang mana kurikulum ini diganti atas dasar

\footnotetext{
${ }^{9}$ Hikmat et al., "Efektivitas Pembalajaran Daring Selama Masa Pandemi Covid-19: Sebuah Survey Online," Digital Library, UIN SUnan Gung Djati, Bandung (2020).

${ }^{10}$ Noor Amirudin, "Problematika Pembelajaran Bahasa Arab," jurnal Pemikiran dan Keagamaan 1, no. 1 (2017): 11-19.

11 Aziz Fahrurrozi, "Pembelajaran Bahasa Arab: Problematika Dan Solusinya," ARABIYAT: Jurnal Pendidikan Bahasa Arab dan Kebahasaaraban 1, no. 2 (2014).

12 Dindin Jamaluddin et al., "Pembelajaran Daring Masa Pandemik Covid-19 Pada Calon Guru: Hambatan, Solusi Dan Proyeksi," Karya Tulis Ilmiah UIN Sunan Gunung Djjati Bandung (2020): 1-10, http://digilib.uinsgd.ac.id/30518/.

${ }^{13}$ Ahmadi, Abu, and Widodo Supriono, Psikologi Belajar, Cetaka Ke-. (Jakarta: Rineka Cipta, 2004).
} 
perubahan yang sangat cepat dalam kehidupan dan tuntutan global yang harus diantisipasi. ${ }^{14}$

Zakiah Daradjat memandang kurikulum sebagai suatu program yang direncanakan dalam bidang pendidikan dan dilaksanakan untuk mencapai sejumlah tujuan-tujuan pendidikan tertentu. ${ }^{15}$ pada masa pandemi ini kurikulum pembelajaran bahasa arab tentunya lebih kompleks karena harus mengakomodir seluruh kebutuhan peserta didik baik dari psikologi siswa, sistem pembelajaran dan lingkungan sosial yang dibatasi oleh jarak. Kurikulum bahasa arab harus bisa mengantisipasi perubahan itu dan merespon tuntutan zaman yang selalu berubah. Kurikulum Bahasa Arab diarahkan untuk menyiapkan peserta didik madrasah mampu beradaptasi dengan perubahan sehingga lulusannya kompatibel dengan tuntutan zamannya dalam membangun peradaban bangsa.

Berdasarkan pembahasan dari latar belakang tersebut, penulis berminat untuk menggambarkan dan menganalisis tentang kurikulum pembelajaran bahasa arab yang cocok digunakan pada masa pandemi covid-19, mulai dari konsep kurikulum, konsep pembelajaran bahasa arab dan bagaimana kurikulum tersebut dapat menunjang pembelajaran pada masa pandemi cevod-19.

\section{METODOLOGI PENELITIAN}

Penelitian ini menggunakan pendekatan kualitatif dengan metode studi pustaka (library research). Pengumpulan data dilakukan dengan didasarkan kepada kurikulum bahasa Arab salah satunya telaah kurikulum KMA No 183 Tahun 2019. Hal ini dilakukan karena adanya KMA 183 Tahun 2019 diarahkan untuk menyiapkan peserta didik madrasah mampu beradaptasi dengan perubahan sehingga lulusannya kompatibel dengan tuntutan zamannya dalam membangun peradaban bangsa. Selain itu data pendukung tentunya dibutuhkan seperti beberapa buku teks, jurnal ilmiah dan dokumen serta sumber-sumber data dan atau informasi lainnya yang dianggap memiliki relevansi dengan topik penelitian.

Berdasarkan hal tersebut di atas, maka penelitian ini dianalisis secara deskriptif untuk memberikan gambaran dan keterangan secara jelas, objektif,

\footnotetext{
14 direktorat pendidikan Agama and Kementerian Agama, "Keputusan Menteri Agama Tentang Pedoman Implementasi Kurikulum Pada Madrasah," Keputusan Menteri Agama Tentang Pedoman Implementasi Kurikulum pada Madrasah (2019).

15 Zakiah Daradjat, Ilmu Pendidikan Islam, (Jakarta: Bumi Aksara, 1992), hal. 122.
} 
sistematis, analitis dan kritis mengenai kurikulum pembelajaran bahasa arab yang sesuai pada masa pandemi covid-19.

\section{HASIL PENELITIAN DAN PEMBAHASAN}

Para guru dituntut untuk belajar ekstra keras memutar otak mendesain kurikulum bukan hanya bagaimana materi itu tersampaikan, tetapi bagaimana metode yang dipilih serta konten yang tepat untuk pembelajaran tersebut selama belajar dari rumah. ${ }^{16}$

Adapun hal yang harus diperhatikan dalam mengembangkan kurikulum di masa pandemi adalah sebagai berikut: ${ }^{17}$ 1) Pengembangan keterampilan sosial: aspek dari pengembangan tersebut dapat berpengaruh pada kecerdasan emosional, mengapresiasi pada keanekaragaman, dan kemampuan berbahasa. Hal ini merupakan kesempatan bagi kita untuk meningkatkan bahasa kedua setelah bahasa ibu. 2) Perkembangan kepribadian: yang dapat kita kembangkan keterampilan personal bagi peserta didik. Ekspresi artistik (jiwa seni): misalnya terhadap musik, tari terutama terhadap sastra, menulis atau menyampaikan cerita. Harus kita sadari bahwa peserta didik memiliki kebutuhan dasar terhadap bagaimana mengekspresikan pikiran dan perasaan mereka. 3) Melek informasi: yaitu bagaimana caranya meningkatkan peserta didik terhadap melek informasi. Yaitu dengan melakukan penugasan yang berkaitan dengan membuat kliping atau informasi dari televisi dan dapat menceritakan kembali terhadap informasi yang diperoleh. Hal ini dapat meningkatkan kemampuan siswa dalam berbicara dan menyerap informasi dengan baik. 4) Penyelidikan ilmiah: yaitu aspek ini dengan memperhatikan lingkungan sekitar atau studi global dan lain sebagainya.

Dengan memperhatikan hal di atas diharapkan kurikulum dapat disusun dengan sebaik-baiknya. Kurikulum merupakan sebuah sistem, memiliki perangkat unsur yang secara teratur saling berkaitan sehingga membentuk totalitas, artinya kurikulum itu dipandang memiliki sejumlah komponen yang saling berhubungan, sebagai kesatuan yang bulat untuk mencapai tujuan. Komponen-komponen

\footnotetext{
${ }^{16}$ Chairiyaton Nabila Hilmy Zhafira, Yenny Ertika, “Pembelajaran Jarak Jauh Di Masa Pandemi," Jurnal L Bisnis Dan Kajian Strategi Manajemen, 2020.

${ }^{17}$ Sri Winarni And Syahrial, "Inovasi Kurikulum Dan Pembelajaran Pada Masa Pandemi Civid-19," Jurnal Ilmiah Wahana Pendidikan Https://Jurnal.Unibrah.Ac.Id/Index.Php/JIWP, 2020.
} 
tersebut yaitu komponen tujuan, isi, proses, serta evaluasi. Untuk merancang kurikulum pada masa pandemi tentunya hal tersebut memiliki keterkaitan yang erat dan tidak dapat dipisahkan.

\section{Tujuan Pembelajaran}

Sebelum menetapkan tujuan pembelajaran terlebih dahulu seorang guru harus memperhatikan profil Peserta Didik baik dari bakat, minat, gaya belajar, kegemaran, keadaan orang tua dan pekerjaannya, jam berapa orang tua bekerja dan ada di rumah, memahami murid, memahami orang tua merupakan langkah awal yang penting untuk pembelajaran jarak jauh ${ }^{18}$. Perlu kita ketahui belajar bahasa diperlukan agar seseorang dapat berkomunikasi dengan baik dan benar dengan sesamanya dan lingkungannya, baik secara lisan maupun tulisan. Tujuan pembelajaran bahasa Arab tentunya harus memperhatikan tingkat peserta didik atau level, tidak lupa pula latar belakang peserta didik sangat berpengaruh pada pencapaian tujuan pembelajaran ${ }^{19}$. Pada masa pandemi covid-19 pembelajaran harus disusun sedemikian rupa bersama orang tua untuk mencapai tujuan pembelajaran tersebut.

Pelajaran Bahasa Arab merupakan suatu mata pelajaran yang diarahkan untuk mendorong, membimbing, mengembangkan, membina kemampuan serta menumbuhkan sikap positif terhadap bahasa Arab baik reseptif maupun produktif. ${ }^{20}$ Kemampuan reseptif yaitu kemampuan untuk memahami pembicaraan orang lain dan memahami bacaan. Kemampuan produktif yaitu kemampuan menggunakan bahasa sebagai alat komunikasi baik secara lisan maupun secara tertulis.

Dalam KMA No 183 tahun 2019 dijelaskan Mata pelajaran Bahasa Arab memiliki tujuan sebagai berikut:21 1) Mengembangkan kemampuan dalam bahasa Arab sebagai alat komunikasi global, baik lisan maupun tulis, yang mencakup empat kecakapan berbahasa, yakni menyimak (istima'), berbicara (kalam), membaca

\footnotetext{
${ }^{18}$ Agustien Lilawati, "Jurnal Obsesi : Jurnal Pendidikan Anak Usia Dini Peran Orang Tua Dalam Mendukung Kegiatan Pembelajaran Di Rumah Pada Masa Pandemi," Jurnal Pendidikan Anak Usia Dini (2020).

${ }^{19}$ Ismail Suardi Wekke, "Kurikulum Bahasa Arab Di Lembaga Pendidikan," Karsa, 2014.

${ }^{20}$ Madrasah Et Al., "Keputusan Menteri Agama Tentang Pedoman Implementasi Kurikulum Pada Madrasah."

${ }^{21}$ Ibid.
} 
(qira'ah), dan menulis (kitabah). 2) Menumbuhkan kesadaran tentang pentingnya bahasa Arab sebagai salah satu bahasa asing untuk menjadi alat utama belajar, khususnya dalam mengkaji sumber-sumber ajaran Islam yang terus bersambung hingga sumber asalnya yaitu al-Qur'an dan hadits.

Mencermati tujuan pembelajaran bahasa Arab sebagaimana yang disebutkan di atas, sungguh sangat ideal dengan tujuan pembelajaran pada abad 21 . Pembelajaran abad 21 sebagai proses belajar yang dibangun oleh guru untuk mengembangkan kreativitas berpikir yang dapat meningkatkan kemampuan peserta didik dalam mengonstruksi pengetahuan baru sebagai upaya untuk meningkatkan penguasaan yang baik terhadap materi pelajaran. Pembelajaran di abad 21 menuntut peserta didik untuk memiliki keterampilan, pengetahuan dan kemampuan di bidang teknologi, media dan informasi, keterampilan pembelajaran dan inovasi serta keterampilan hidup dan karir. ${ }^{22}$

Adapun penjelasan mengenai framework pembelajaran abad 21 sebagaimana dijelaskan dalam penelitian Ayu Desrani dkk adalah sebagai berikut: ${ }^{23}$ 1) Kemampuan berpikir kritis dan pemecahan masalah (Critical-Thinking and Problem-Solving Skills), adalah kemampuan berpikir secara kritis, lateral, dan sistemik, terutama dalam konteks pemecahan masalah. Peserta didik dilatih untuk memberikan penalaran yang masuk akal dalam memahami dan membuat pilihan yang rumit, memahami interkoneksi antara sistem. 2) Kemampuan berkomunikasi dan bekerja sama (Communication and Collaboration Skills. Pembelajaran secara berkelompok, kooperatif melatih peserta didik untuk berkolaborasi dan bekerja sama. Hal ini juga untuk menanamkan kemampuan bersosialisasi dan mengendalikan ego serta emosi. Dengan demikian, melalui kolaborasi akan tercipta kebersamaan, rasa memiliki, tanggung jawab, dan kepedulian antar anggota; 3) Kemampuan mencipta dan membaharui (Creativity and Innovation Skills), mampu mengembangkan kreativitas yang dimilikinya untuk menghasilkan berbagai terobosan yang inovatif; dan 4) Literasi teknologi informasi dan komunikasi

\footnotetext{
${ }^{22}$ Husni Abdullah et al., "Pendidikan Abad Ke - 21 Dalam Pengajaran Bahasa Arab Di Sekolah Menengah Di Malaysia: Amalan Dan Cabaran," in 5th International Research Management \& Innovation Conference (5th IRMIC 2018), 2018.

${ }^{23}$ Ayu Desrani, Et Al, "HIGHER ORDER THINKING SKILLS THE 21st CENTURY," In International Conference On Language, Education, Economic And Social Science, 2014, Https://Proceedings.IaipdNganjuk.Ac.Id/Index.Php/Icoleess/Article/View/12/2.
} 
(Information and Communications Technology Literacy) untuk meningkatkan kinerja dan aktivitas sehari-hari.

Materi dan Isi

Dunia pendidikan harus kembali mengajarkan cara belajar (Learning How to Learn), bukan Learning What to Learn (belajar tentang sesuatu). Semua ini tercermin dari isi pembelajaran daring ini di mana awalnya para guru masih berkutat tentang konten atau materi yang dibuat untuk memberi tahu peserta didik daripada membiarkan mereka untuk mencari tahu sendiri. ${ }^{24}$

Banyaknya tugas dari guru sering kali menjadi keluhan dalam pembelajaran daring. Beban belajar peserta didik tentunya harus diperhitungkan, terukur, baik secara materi maupun waktu. Tentunya perlu diingat bahwa pembelajaran di kelas tidak setiap saat diisi dengan tugas atau mengerjakan soal dalam jumlah banyak. Guru bisa memberikan tugas mengamati, mencoba, dan menganalisis, sehingga lebih menarik dan menantang.

Menurut Permendikbud tahun 2013 Standar Isi adalah kriteria mengenai ruang lingkup materi dan tingkat kompetensi untuk mencapai kompetensi lulusan pada jenjang dan jenis pendidikan tertentu. Sementara menurut Kemenag Standar Isi adalah kriteria mengenai ruang lingkup materi dan tingkat kompetensi untuk mencapai kompetensi lulusan pada jenjang dan jenis pendidikan tertentu. Ruang lingkup materi dan tingkat kompetensi peserta didik yang harus dipenuhi atau dicapai pada suatu satuan pendidikan dalam jenjang dan jenis pendidikan tertentu dirumuskan dalam Standar Isi untuk setiap mata pelajaran.

Jika dihubungkan dengan pelajaran bahasa Arab, maka standar isi adalah ruang lingkup dan kompetensi mata pelajaran bahasa Arab yang harus dicapai oleh setiap peserta didik. Dengan mencermati definisi tersebut, maka standar isi merupakan batas minimal yang harus dicapai oleh peserta didik dalam ruang lingkup dan kompetensi bahasa Arab. ${ }^{25}$

Pandemi Covid-19 kiranya bisa menjadi pintu masuk untuk mengubah pembelajaran tekstual menjadi kontekstual. ${ }^{26}$ Pembelajaran kontekstual

\footnotetext{
24 Dian Ratu, Ayu Uswatun, and Hascaryo Pramudibyanto, "Pendidikan Dalam Masa Pandemi Covid19," Jurnal Sinestesia (2020).

25 Kemenag, "Keputusan Menteri Agama Tentang Pedoman Implementasi Kurikulum Pada Madrasah."

26 Ikhwan Mahmudi, "Bahasa Sebagai Sarana Berpikir Ilmiah: Analisis Pembelajaran Bahasa Kontekstual," Universitas Negeri Jakarta (2016).
} 
merupakan konsep belajar yang mengaitkan antara materi pelajaran dalam kehidupan sehari-hari. Peserta didik diharapkan dapat menemukan dan mengembangkan pengetahuan dan keterampilan baru sesuai dengan pengetahuan yang mereka miliki. Dengan demikian, mereka akan lebih memahami dan lebih memaknai pengetahuannya. ${ }^{27}$

Pembelajaran kontekstual merupakan konsep yang membantu guru mengaitkan antara materi yang diajarkannya dengan situasi dunia nyata dan mendorong siswa membuat hubungan antara pengetahuan yang dimilikinya dengan penerapannya dalam kehidupan mereka sebagai anggota keluarga dan masyarakat. Dalam praktiknya, pembelajaran kontekstual dilakukan secara autentik yaitu pembelajaran yang mengutamakan pengalaman nyata, pengetahuan bermakna dalam kehidupan, dekat dengan kehidupan nyata sehingga sangat cocok jika diterapkan di massa pandemi seperti sekarang ini.

\section{Proses Pembelajaran}

Komponen ini memiliki peran yang sangat penting, sebab berhubungan dengan implementasi kurikulum. Bagaimanapun idealnya tujuan tidak akan berhasil tanpa strategi. proses meliputi rencana metode dan perangkat kegiatan yang direncanakan untuk mencapai tujuan tertentu. ${ }^{28}$ Pada masa pandemi covid-19 terdapat perbedaan dalam menentukan tujuan dan materi pembelajaran, hal ini tentu menjadi konsekuensi pula terhadap penentuan strategi pembelajaran yang hendak dikembangkan. Adapun proses yang dapat digunakan dalam pembelajaran bahasa Arab di masa pandemi adalah sebagai berikut:

\section{Menentukan Metode Pembelajaran}

Metode adalah upaya mengimplementasikan rencana yang sudah disusun dalam kegiatan nyata agar tujuan yang telah disusun tercapai secara optimal. Metode adalah $a$ way in achieving something. ${ }^{29}$ Pada masa pandemi covid-19 guru harus dapat memilih metode yang dapat digunakan sesuai dengan keadaan saat ini baik dari sisi kemampuan siswa dan orang tua. Pada masa pandemi dan era new normal sepertinya pembelajaran kita mengarah pada praktik (Blended Learning)

\footnotetext{
27 Mitra Pramita, Sri Mulyati, and Hery Susanto, "Implementasi Desain Pembelajaran Pada Kurikulum 2013 Dengan Pendekatan Kontekstual," Jurnal Pendidikan (2016).

${ }^{28}$ Muhandis Azzuhri, "Metode Dan Media Pembelajaran Bahasa Arab Berbasis Internet Di Era Teknologi Informasi," INSANIA : Jurnal Pemikiran Alternatif Kependidikan 14, no. 3 (1970): 348-445. 29 Dindin Jamaluddin et al., "Pembelajaran Daring Masa Pandemik Covid-19 Pada Calon Guru: Hambatan, Solusi Dan Proyeksi," Karya Tulis Ilmiah UIN Sunan Gunung Djjati Bandung (2020).
} 
atau pembelajaran yang memadukan pembelajaran tatap muka dan pembelajaran online. Untuk memperkuat pencapaian kompetensi peserta didik dengan pendekatan ilmiah (scientific), maka perlu diterapkan proses pembelajaran berbasis penyingkapan/penelitian (discovery/inquiry learning). Selain itu untuk mendorong kemampuan peserta didik untuk menghasilkan karya kontekstual, baik individual maupun kelompok maka sangat disarankan menggunakan pendekatan pembelajaran yang menghasilkan karya (project based learning), dan pembelajaran berbasis masalah (problem based learning). 30

Project based learning ini diprakarsai oleh hasil implikasi dari Surat Edaran Mendikbud no.4 tahun 2020. Project based learning ini memiliki tujuan utama untuk memberikan pelatihan kepada pelajar untuk lebih bisa berkolaborasi, gotong royong, dan empati dengan sesama. Metode project based learning ini sangat efektif diterapkan untuk para pelajar dengan membentuk kelompok belajar kecil dalam mengerjakan projek, eksperimen, dan inovasi. Metode pembelajaran ini sangatlah cocok bagi pelajar yang berada pada zona kuning atau hijau. Dengan menjalankan metode pembelajaran yang satu ini, tentunya juga harus memperhatikan protokol kesehatan yang berlaku.

Metode pembelajaran bahasa arab tentunya harus disesuaikan dengan Karakteristik proses pembelajaran bahasa Arab yaitu: ${ }^{31}$ 1) Proses pembelajaran dilaksanakan dengan menggunakan bahasa sasaran (Arab). Dengan pembelajaran menggunakan bahasa Arab guru diharapkan menjadi model penutur sekaligus juga sebagai media bagi peserta didik untuk mendapatkan kosa kata baru; 2) Menjadikan resource (sumber) yang ada di lingkungan madrasah sebagai sumber pembelajaran; dan 3) Pembelajaran Bahasa Arab yang pertama adalah pembelajaran bahasa lisan, selanjutnya bahasa tulis. Sedangkan urutannya adalah mengajarkan mendengar, diikuti berbicara, membaca dan menulis.

Menentukan teknologi yang digunakan

Pandemi cobid-19 saat ini memberikan banyak sekali perubahan, guru maupun siswa dan orang tua dituntut untuk menguasai teknologi untuk mendukung keberlangsungan pembelajaran. Keadaan ini juga sesuai dengan abad

\footnotetext{
${ }^{30}$ Kebudayaan Kementerian Pendidikan, "Mendikbud Terbitkan SE Tentang Pelaksanaan Pendidikan Dalam Masa Darurat Covid-19," Kemdikbud.

${ }^{31}$ Agama and Agama, "Keputusan Menteri Agama Tentang Pedoman Implementasi Kurikulum Pada Madrasah."
} 
21 pada masa pengetahuan (knowledge age) seolah-olah semuanya tergantung pada teknologi informasi dan komputasi. Meskipun teknologi informasi dan komunikasi adalah katalis penting untuk memindahkan pembelajaran dari masa industri (industrial age) ke masa pengetahuan (knowledge age) namun hal tersebut merupakan alat bukan penentu hasil dalam proses pembelajaran. Dalam konteks perkembangan IPTEK ini, guru dituntut memberikan peran penting dalam pembelajaran dari sekedar memahamkan peserta didik karena peran ini sudah banyak diambil alih oleh teknologi, tapi guru harus mampu membangkitkan rasa ingin tahu, harapan (ekspektasi) yang tinggi, menjadi teladan, dan menjadi inspirasi bagi semua peserta didik. 32

Bukan hal yang sulit bagi peserta didik untuk mengikuti pembelajaran dari rumah menggunakan teknologi, yang notabennya mereka merupakan generasi digital untuk mengubah pembelajarannya dari dunia nyata ke dunia maya ${ }^{33}$. Dalam menentukan proses pembelajaran yang digunakan, guru harus memilih teknologi yang sesuai dengan kondisi murid dan orang tua. Teknologi tidak perlu yang canggih namun dipastikan efektif dan mampu mendukung tujuan belajar. Meskipun pendidikan di Indonesia ikut terdampak covid-19, namun dibalik semua itu ada hikmah dan pelajaran yang dapat diambil. Adanya kebijakan dari Kemendikbud untuk melakukan pembelajaran secara daring, dapat memberikan manfaat yaitu meningkatkan kesadaran untuk menguasai kemajuan teknologi saat ini dan juga dapat mengatasi permasalahan sistem pendidikan di Indonesia. ${ }^{34}$ Adapun teknologi yang dapat digunakan selama proses pembelajaran dibagi menjadi 3 bagian yaitu:

\footnotetext{
${ }^{32}$ Luluk Humairo Pimada and Muhammad Afif Amrulloh, "Penerapan Media Elektronik Pada Pembelajaran Bahasa Arab," Lahjah Arabiyah: Jurnal Bahasa Arab dan Pendidikan Bahasa Arab 1, no. 2 (2020): 120-128.

33 Aulia Riska Nugraheny and Mahasiswi, "Peran Teknologi, Guru Dan Orang Tua Dalam Pembelajaran Daring Di Masa Pandemi," Peran Teknologi, Guru Dan Orang Tua Dalam Pembelajaran Daring Di Masa Pandemi (2020).

${ }^{34}$ Ni Komang Sari Astini, "Pemanfaatan Teknologi Informasi Dalam Pembelajaran Tingkat Sekolah Dasar Pada Masa Pandemi Covid-19," Jurnal Lembaga Penjaminan Mutu STKIP Agama Hindu Amlapura (2020).
} 
Tabel 1. Teknologi pembelajaran
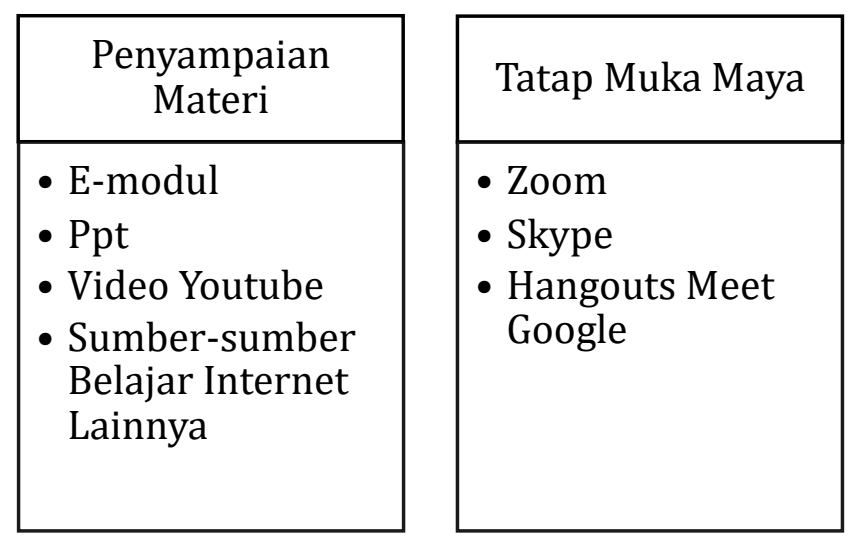

Teknologi di atas merupakan sebuah media yang dapat digunakan untuk membantu dan menunjang pembelajaran pada masa pandemi covid-19. Pertama, yaitu penyampaian materi guru dapat menggunakan e-modul, ppt yang dibuat terlebih dahulu oleh guru, video yang dapat diakses di youtube atau pemanfaatan video orang lain yang ada di youtube, tentunya banyak sekali konten-konten bahasa Arab yang dapat di akses untuk semua kalangan. Pembelajaran mulai dari kaidah, melatih kemahiran menyimak dan berbicara dapat menggunakan konten dari Arab podcasts yang sering saya gunakan, pengajarnya dari Mesir langsung sehingga secara tidak langsung hal tersebut dapat membentuk kemahiran berbicara dengan baik. Tentunya media ini dapat digunakan di setiap mata pelajaran apa saja terutama pembelajaran bahasa Arab situ sendiri. Untuk menggunakan beberapa teknologi tersebut guru dituntut harus mempunyai pengetahuan mendalam, sehingga pemanfaatannya pun lebih maksimal dan dapat mensosialisasikan kepada orang tua dan murid secara jelas. ${ }^{35}$

Dalam penelitian Ahmad Taufik mengatakan bahwa internet atau pembelajaran dalam jaringan berperan penting sebagai pembantu tambahan dalam situasi belajar, dampak positif terhadap internet dalam pembelajaran bahasa arab meliputi: ${ }^{36}$ 1) dengan adanya internet atau TIK maka akan muncul aplikasi-aplikasi yang mempermudah dalam pembelajaran tersebut. 2) tampilan dalam penggunaan media TIK akan lebih menarik minat siswa untuk belajar. 3) pembelajaran dengan

\footnotetext{
${ }^{35}$ A Aisa and L Lisvita, "Penggunaan Teknologi Informasi Dalam Pembelajaran Online Masa Covid19," JoEMS (Journal of Education and Management ... (2020).

36 Taufik, "Strategi Pembelajaran Bahasa Arab Berbasis Internet."
} 
internet menyebabkan peserta didik mudah mengenal dan memperoleh materi yang akurat. 4) terjadinya distribusi pendidikan ke semua penjuru tanah air dan kapasitas daya tampung yang tidak terbatas dimungkinkan lagi tidak memerlukan ruang kelas, dan proses yang tidak terbatas oleh waktu bagai kegiatan dilakukan tatap muka.

Penggunaan media pembelajaran berbasis TIK ini harus tetap disesuaikan dengan berbagai pihak, baik siswa dan orang tua merupakan sosialisasi utama dalam penerapan media berbasis TIK. Tidak berhenti di situ dalam pembelajaran daring harus tetap memperhatikan metode dan konten materi agar sampai kepada siswa. Dalam penelitian yang dilakukan oleh Nanang Kosim dkk mengatakan bahwa solusi dalam mengatasi pembelajaran daring harus mempertimbangkan hal-hal sebagai berikut: 1) membuat modul pembelajaran bahasa arab yang sudah dilengkapi dengan TIK dan mudah diakses. 2) memperkuat urgensi berbahasa arab bagi siswa dan mahasiswa. 3) membuat pola pembelajaran bahasa arab secara $e$ learning dan interaktif. 37

\section{Sosialisasi Proses Pembelajaran}

Setelah semua telah selesai disusun oleh guru dengan baik. Selanjutnya guru harus melakukan sosialisasi proses pembelajaran tersebut kepada siswa terutama orang tua bagi kelas pemula. Sosialisasi tersebut dapat menjelaskan baik dari tujuan pembelajaran, rencana pembelajaran, bukti belajar, kriteria yang diharapkan, termasuk jadwal belajar. Hal tersebut sangat penting untuk disosialisasikan terlebih dahulu agar pembelajaran dapat berjalan dengan baik dan lancar. ${ }^{38}$ Refleksi

Melalui refleksi pembelajaran diperoleh informasi positif tentang bagaimana guru dapat meningkatkan kualitas pembelajaran meliputi perencanaan, keterlaksanaan dan hasil pembelajaran yang dikelolanya. Selain itu juga sebagai bahan observer untuk mengetahui sejauh mana hasil belajar dicapai. ${ }^{39}$

\footnotetext{
${ }^{37}$ Kosim et al., "Pembelajaran Bahasa Arab Melalui Daring; Problematika, Solusi Dan Harapan."

${ }^{38}$ Agustin Lilawati, "Peran Orang Tua Dalam Mendukung Kegiatan Pembelajaran Di Rumah Pada Masa Pandemi," Jurnal Obsesi : Jurnal Pendidikan Anak Usia Dini (2020).

39 Sumaryanta, Pradjitno, and Agustina, Modul Pengembangan Keprofesian Berkelanjutan Sekolah Dasar Kelas Tinggi Terintegrasi Penguatan Pendidikan Karakter Dan Pengembangan Sosial (Jakarta: Direktorat Jenderal Guru dan Tenaga Kependidikan Kementerian Pendidikan dan Kebudayaan, 2018).
} 
Kegiatan refleksi ini baik untuk dilakukan setiap kali pembelajaran selesai atau di akhir sesi pembelajaran. Hal tersebut dapat membantu peserta didik melakukan perbaikan terhadap proses pembelajaran dan pencapaian pembelajaran serta dapat membawa kepuasan siswa. ${ }^{40}$

Apabila guru berpikir secara reflektif, maka guru akan merancang kembali perencanaan mengajar yang lebih baik dan tindak lanjut lain yang dapat membantu siswa meraih kembali hasil belajar yang optimal. Dengan demikian, tidak hanya siswa yang memiliki tugas untuk belajar, tetapi guru itu sendiri juga memiliki tugas untuk selalu berproses menyelenggarakan pembelajaran yang baik.

\section{Evaluasi}

Penilaian pembelajaran di madrasah adalah proses pengumpulan dan pengelolaan informasi untuk mengukur kemampuan pencapaian hasil belajar peserta didik pada mata pelajaran bahasa Arab di madrasah. Berdasarkan karakteristik mata pelajaran bahasa Arab dalam kurikulum KMA No 183 tahun 2014, maka penilaian bahasa Arab diarahkan untuk mengetahui dan mendorong peserta didik dalam sikap dan perilaku yang tercermin dalam hal-hal sebagai berikut:41 1) Sejauh mana peserta didik mampu menggunakan pendengarannya untuk menyimak pembicaraan bahasa Arab (istima'). 2) Sejauh mana peserta didik mampu merespon pembicaraan dalam komunikasi verbal dengan bahasa Arab (kalam); 3) Sejauh mana peserta didik mampu menangkap gagasan ataupun ide pokok dalam teks berbahasa Arab (qiroah); dan. 4) Sejauh mana peserta didik mampu menggunakan bahasa Arab untuk mengekspresikan rasa, gagasan dan pikiran dalam bahasa tulis (kitabah)

Dengan demikian penilaian hasil belajar bahasa Arab harus dilakukan dengan penilaian yang autentik dan komprehensif, menggunakan berbagai teknik penilaian yang saling melengkapi. Hasil penilaian pun harus benar-benar menggambarkan kemampuan nyata peserta didik dalam aspek menyimak, berbicara, membaca dan menulis.

Sesuai dengan standar penilaian pendidikan yang ada dalam kurikulum 2013 dijelaskan bahwa penilaian mencakup penilaian autentik, penilaian diri, penilaian

\footnotetext{
${ }^{40}$ Luh Devi Herliandry et al., "Pembelajaran Pada Masa Pandemi Covid-19," JTP - Jurnal Teknologi Pendidikan (2020).

${ }^{41}$ Agama and Agama, "Keputusan Menteri Agama Tentang Pedoman Implementasi Kurikulum Pada Madrasah."
} 
berbasis portofolio, ulangan, ulangan harian, ulangan tengah semester, ulangan akhir semester, ujian tingkat kompetensi, ujian mutu tingkatan kompetensi, ujian nasional, ujian sekolah . Dari sini dapat dijelaskan bahwa dalam kurikulum 2013, penilaian tidak hanya mencakup penilaian hasil belajar (assessment of learning), melainkan juga penilaian untuk mengoptimalkan perbaikan proses pembelajaran (assessment for learning) dan penilaian sebagai bagian dari proses pembelajaran peserta didik (assessment as learning). Umpan balik guru kepada peserta didik akan menentukan tercapainya fungsi penilaian sebagai perbaikan proses pembelajaran dan peningkatan belajar peserta didik. Penilaian itu sendiri terdiri dari tiga aspek yaitu sikap, pengetahuan dan keterampilan. Untuk melakukan apa yang harus dinilai hendaknya kita berpacu pada indikator-indikator serta kata kerja operasional dalam Bloom atau yang disebut taksonomi Bloom. ${ }^{42}$

Sikap, yaitu kegiatan yang dilakukan oleh pendidik untuk memperoleh informasi deskriptif mengenai perilaku peserta didik. Aspek sikap ini termasuk minat, penghargaan, dan cara penghargaan. Sikap adalah gejala internal yang berdimensi afektif berupa kecenderungan untuk mereaksi atau merespon dengan cara yang relatif tetap terhadap obyek orang atau benda, termasuk mata pelajaran, seperti peserta didik menjalankan sikap kritis terhadap materi yang sedang dipelajari. Sedangkan minat adalah kecenderungan yang tinggi atau keinginan yang besar terhadap sesuatu. Misalnya, peserta didik memberikan perhatian yang tinggi pada mata pelajaran Bahasa Arab.

Pengetahuan, yaitu merupakan kegiatan yang dilakukan untuk mengukur kemampuan dari peserta didik dalam mengulang atau menyatakan kembali konsep/prinsip yang telah dipelajari dalam proses pembelajaran yang telah didapatnya. Semua jenis dan teknik penilaian harus diarahkan untuk mengukur pencapaian keterampilan berpikir tingkat tinggi atau Higher Order Thinking Skills (HOTS). Dengan demikian penilaian tidak sekedar mengukur taraf pengetahuan peserta didik tapi berupa penerapan, analisis, evaluatif hingga menemukan inovasi baru. ${ }^{43}$

\footnotetext{
${ }^{42}$ Susan M. Brookhart, How to Asses Hogher-Order Thinking Skill in Your Classroom, Book, 2010.

${ }^{43}$ Lorin W. Anderson, D.R. David R. Krathwohl, and B. S. Bloom, A Taxonomy for Learning, Teaching, and Assessing, New York Longman, 2001.
} 
Keterampilan, yaitu kegiatan yang dilakukan untuk mengukur kemampuan peserta didik menerapkan pengetahuan dalam melakukan tugas tertentu. Penilaian keterampilan dilakukan dengan menggunakan tes kinerja (unjuk kerja), proyek dan portofolio. Penilaian kinerja merupakan penilaian untuk melakukan suatu tugas dengan mengaplikasikan pengetahuan dan keterampilan yang dibutuhkan. Pada penilaian kinerja, penekanan penilaiannya dapat dilakukan pada proses atau produk. Pada saat penyusunan instrumen penilaian kinerja, perlu disiapkan pula rubrik penilaiannya. Untuk penilaian proyek, tugas yang harus diselesaikan memerlukan periode/waktu tertentu. Tugas proyek bisa berupa rangkaian kegiatan mulai dari (1) perencanaan, (2) pengumpulan data, (3) pengorganisasian, (4) pengolahan, (5) penyajian data, dan (6) pelaporan. Sedangkan untuk portofolio, bisa berupa kumpulan dokumen atau teknik penilaian.

Penilaian di dalam kelas, harus dapat mengimplementasikan ketiga bentuk penilaian di atas. Salah satu model alternatif penilaian yang dapat diimplementasikan di masa pandemi covid-19 atau pembelajaran jarak jauh adalah tes daring. Banyak sekali media pembelajaran yang dapat kita gunakan untuk mengukur kemampuan siswa. Seperti wondershare quiz creator, help teaching, quizizz, kahoot, easyLMS, pollmaker, classmarker, google form dll.

Menurut Nana Sudjana kurikulum merupakan niat dan harapan yang dituangkan ke dalam bentuk rencana maupun program pendidikan yang dilaksanakan oleh para pendidik di sekolah. ${ }^{44}$ Kurikulum sebagai niat dan rencana, sedangkan pelaksanaannya adalah proses belajar mengajar. Al-Quran telah menjelaskan bahwa proses belajar mengajar harus dilandasi dengan kewajiban yang dikaitkan dengan niat karena Allah SWT, dimana kewajiban seorang guru adalah mengajarkan dan mengamalkan ilmu, sedangkan murid mempunyai kewajiban menuntut ilmu dari guru tersebut. Keduanya merupakan fitrah manusia yang terjadi dalam proses belajar mengajar dimana kedua-duanya saling berinteraksi untuk mencapai tujuan. Seorang guru sebagai pendidik hendaknya menyadari bahwa mengajar merupakan kewajiban yang harus dilaksanakan dengan mengutamakan kepentingan para muridnya dibandingkan kepentingan sendiri dengan niat yang tulus karena Allah SWT, sebab Allah SWT telah memberikan

\footnotetext{
${ }^{44}$ Nana Sudjana, "Pembinaan Dan Pengembangan Kurikulum Di Sekolah," Bandung (1989).
} 
potensi pada diri manusia berupa fitrah yang melekat pada dirinya berupa panca indra dan daya pikir untuk mendapatkan berbagai macam-macam ilmu pengetahuan melalui proses pembelajaran. ${ }^{45}$ Dalam proses pembelajaran tersebut yaitu pendidik dan peserta didik. Artinya dalam proses pembelajaran di masa pandemi pun pendidik benar-benar harus mempunyai strategi atau konsep pembelajaran untuk mencapai tujuan dari kurikulum itu sendiri karena pembelajaran tidak dilaksanakan seperti biasanya yaitu daring atau melalui online menggunakan internet. ${ }^{46}$

Jadi, dari hasil penelitian dan pembahasan di atas dapat kita simpulkan bahwa komponen dalam kurikulum pembelajaran bahasa arab di masa pandemi saat ini haruslah kompleks artinya disesuaikan dengan keadaan peserta didik dan kondisi orang tua komunikasi yang baik sangat diperlukan. Mempunyai strategi dengan metode dan media yang interaktif atau media yang kreatif sangat dapat membantu untuk menunjang dan mencapai tujuan pembelajaran.

\section{KESIMPULAN}

Pada masa pandemi covid-19 pembelajaran bahasa Arab mengalami banyak problematika dan kendala. Kurikulum menjadi landasan utama untuk mencapai tujuan pembelajaran pada saat ini. Oleh karena konsep pengembangan kurikulum pembelajaran harus disesuaikan dengan kondisi pembelajaran daring atau pembelajaran jarak jauh. Kurikulum ini mencakup 4 komponen yaitu: 1) tujuan pembelajaran, tujuan pembelajaran bahasa arab pada masa pandemi pun masih berfokus kepada bahasa sebagai alat komunikasi global dan bahasa arab sebagai alat komunikasi global dan memahami agama dari sumber-sumber berbahasa arab. Tentunya tetap menyesuaikan pembelajaran saat ini pada abad 21. 2) Isi/materi, diharapkan guru fokus pada konten atau bagaimana sampainya materi tersebut kepada siswa dan tidak bertujuan untuk menyelesaikan materi, materi juga harap berbentuk kontekstual agar lebih bisa dipahami siswa dalam dunia nyata. 3) Proses pembelajaran, mencakup strategi, metode, media yang memang harus disesuaikan pada masa pandemi covid 19, pemanfaatan teknologi sangat diperlukan untuk

\footnotetext{
45 Asep Hernawan Herry and Dewi Andriyani, "Hakikat Kurikulum Dan Pembelajaran," Modul Pembelajaran (2014).

46 Ahmad Munajim, Barnawi Barnawi, and Fikriyah Fikriyah, "Pengembangan Kurikulum Pembelajaran Di Masa Darurat," DWIJA CENDEKIA: Jurnal Riset Pedagogik (2020).
} 
menunjang pembelajaran dan tetap harus disosialisasikan terlebih dahulu kepada murid dan orang tua agar pembelajaran berlangsung dengan baik. 4) Evaluasi, evaluasi dilakukan tidak hanya kepada hasil belajar, akan tetapi pada proses pembelajaran juga perlu untuk dievaluasi untuk meningkatkan dan mengoptimalkan tujuan pembelajaran. Untuk evaluasi hasil belajar dapat berbasis project agar terhindar dari pertukaran jawaban antar siswa.

\section{DAFTAR PUSTAKA}

Abdullah, Husni, Abd Razif Zaini, Khairatul Akmar Ab Latif, Hasanah Ihsan, Ku Fatahiyah $\mathrm{Ku}$ Azizan, Wan Sakinah Wan Ngah, and Naqibah Mansor. "Pendidikan Abad Ke - 21 Dalam Pengajaran Bahasa Arab Di Sekolah Menengah Di Malaysia: Amalan Dan Cabaran." In 5th International Research Management \& Innovation Conference (5th IRMIC 2018), 2018.

Agama, direktorat pendidikan, and Kementerian Agama. "Keputusan Menteri Agama Tentang Pedoman Implementasi Kurikulum Pada Madrasah." Keputusan Menteri Agama Tentang Pedoman Implementasi Kurikulum pada Madrasah (2019).

Ahmadi, Abu, and Widodo Supriono. Psikologi Belajar. Cetaka Ke-. Jakarta: Rineka Cipta, 2004.

Aisa, A, and L Lisvita. "Penggunaan Teknologi Informasi Dalam Pembelajaran Online Masa Covid-19." JoEMS (Journal of Education and Management ... (2020).

Amirudin, Noor. "PROBLEMATIKA PEMBELAJARAN BAHASA ARAB." jurnal Pemikiran dan Keagamaan 1, no. 1 (2017): 11-19.

Anderson, Lorin W., D.R. David R. Krathwohl, and B. S. Bloom. A Taxonomy for Learning, Teaching, and Assessing. New York Longman, 2001.

Asep Hernawan Herry, and Dewi Andriyani. "Hakikat Kurikulum Dan Pembelajaran." Modul Pembelajaran (2014).

Astini, Ni Komang Sari. "Pemanfaatan Teknologi Informasi Dalam Pembelajaran Tingkat Sekolah Dasar Pada Masa Pandemi Covid-19." Jurnal Lembaga Penjaminan Mutu STKIP Agama Hindu Amlapura (2020).

Azzuhri, Muhandis. "Metode Dan Media Pembelajaran Bahasa Arab Berbasis Internet Di Era Teknologi Informasi." INSANIA : Jurnal Pemikiran Alternatif Kependidikan 14, no. 3 (1970): 348-445.

Brookhart, Susan M. How to Asses Hogher-Order Thinking Skill in Your Classroom. Book, 2010.

Desrani, Ayu, Depi Kurniati, and Kamila Adnani. "HIGHER ORDER THINKING SKILLS 
THE 21st CENTURY." In International Conference on Language, Education, Economic and Social Science, 2014. https://proceedings.iaipdnganjuk.ac.id/index.php/icoleess/article/view/12/2.

Fahrurrozi, Aziz. "Pembelajaran Bahasa Arab: Problematika Dan Solusinya." ARABIYAT: Jurnal Pendidikan Bahasa Arab dan Kebahasaaraban 1, no. 2 (2014).

GTK, Kemendikbud. "Kebijakan Kemendikbud Di Masa Pandemi." Https://Gtk.Kemdikbud.Go.Id/.

Herliandry, Luh Devi, Nurhasanah Nurhasanah, Maria Enjelina Suban, and Heru Kuswanto. "Pembelajaran Pada Masa Pandemi Covid-19." JTP - Jurnal Teknologi Pendidikan (2020).

Hikmat, Endang Hermawan, Aldim, and Irwandi. "Efektivitas Pembalajaran Daring Selama Masa Pandemi Covid-19: Sebuah Survey Online.” Digital Library, UIN SUnan Gung Djati, Bandung (2020).

Jamaluddin, Dindin, Teti Ratnasih, Heri Gunawan, and Epa Paujiah. "Pembelajaran Daring Masa Pandemik Covid-19 Pada Calon Guru: Hambatan, Solusi Dan Proyeksi." Karya Tulis Ilmiah UIN Sunan Gunung Djjati Bandung (2020): 1-10. http://digilib.uinsgd.ac.id/30518/.

_—_. "Pembelajaran Daring Masa Pandemik Covid-19 Pada Calon Guru: Hambatan, Solusi Dan Proyeksi." Karya Tulis Ilmiah UIN Sunan Gunung Djjati Bandung (2020).

Kemdikbud, pengelola web. "Kemendikbud Terbitkan Pedoman Penyelenggaraan Belajar Dari Rumah." Jakarta, 28 Mei 2020.

Khasanah, Dian Ratu Ayu Uswatun, Hascaryo Pramudibyanto, and Barokah Widuroyekti. "Pendidikan Dalam Masa Pandemi Covid-19." Jurnal Sinestesia (2020).

Kosim, Nanang, Imam Turmudi, Novy Maryani, and Abdul Hadi. "PEMBELAJARAN BAHASA ARAB MELALUI DARING; PROBLEMATIKA, SOLUSI DAN HARAPAN.” Journal of Food System Research 2, no. 2 (1995): 54-65.

Lilawati, Agustien. "Jurnal Obsesi : Jurnal Pendidikan Anak Usia Dini Peran Orang Tua Dalam Mendukung Kegiatan Pembelajaran Di Rumah Pada Masa Pandemi." Jurnal Pendidikan Anak Usia Dini (2020).

Lilawati, Agustin. "Peran Orang Tua Dalam Mendukung Kegiatan Pembelajaran Di Rumah Pada Masa Pandemi." Jurnal Obsesi : Jurnal Pendidikan Anak Usia Dini (2020).

Mahmudi, Ikhwan. "Bahasa Sebagai Sarana Berpikir Ilmiah: Analisis Pembelajaran Bahasa Kontekstual.” Universitas Negeri Jakarta (2016). 
Munajim, Ahmad, Barnawi Barnawi, and Fikriyah Fikriyah. "Pengembangan Kurikulum Pembelajaran Di Masa Darurat." DWIJA CENDEKIA: Jurnal Riset Pedagogik (2020).

Nabila Hilmy Zhafira, Yenny Ertika, Chairiyaton. "Pembelajaran Jarak Jauh Di Masa Pandemi." Jurnal l Bisnis dan Kajian Strategi Manajemen (2020).

Nugraheny, Aulia Riska, and Mahasiswi. "Peran Teknologi, Guru Dan Orang Tua Dalam Pembelajaran Daring Di Masa Pandemi." Peran Teknologi, Guru Dan Orang Tua Dalam Pembelajaran Daring Di Masa Pandemi (2020).

Orlosky, Donald E. Curriculum Development Issues and Insights (Rand Mcnally Education Series). chicago: rand mcnally, 1978.

Pendidikan, Kebudayaan Kementerian. "Mendikbud Terbitkan SE Tentang Pelaksanaan Pendidikan Dalam Masa Darurat Covid-19." Kemdikbud.

Pimada, Luluk Humairo, and Muhammad Afif Amrulloh. "Penerapan Media Elektronik Pada Pembelajaran Bahasa Arab." Lahjah Arabiyah: Jurnal Bahasa Arab dan Pendidikan Bahasa Arab 1, no. 2 (2020): 120-128.

Pramita, Mitra, Sri Mulyati, and Hery Susanto. "Implementasi Desain Pembelajaran Pada Kurikulum 2013 Dengan Pendekatan Kontekstual." Jurnal Pendidikan (2016).

Ratu, Dian, Ayu Uswatun, and Hascaryo Pramudibyanto. "Pendidikan Dalam Masa Pandemi Covid-19." Jurnal Sinestesia (2020).

Sudjana, Nana. "Pembinaan Dan Pengembangan Kurikulum Di Sekolah." Bandung (1989).

Sumaryanta, Pradjitno, and Agustina. Modul Pengembangan Keprofesian Berkelanjutan Sekolah Dasar Kelas Tinggi Terintegrasi Penguatan Pendidikan Karakter Dan Pengembangan Sosial. Jakarta: Direktorat Jenderal Guru dan Tenaga Kependidikan Kementerian Pendidikan dan Kebudayaan, 2018.

Taufik, Ahmad. "Strategi Pembelajaran Bahasa Arab Berbasis Internet." SELL Journal 5, no. 1 (2020): 55.

Wekke, Ismail Suardi. "KURIKULUM BAHASA ARAB DI LEMBAGA PENDIDIKAN." Karsa (2014).

Winarni, Sri, and Syahrial. "Inovasi Kurikulum Dan Pembelajaran Pada Masa Pandemi Civid-19." Jurnal Ilmiah Wahana Pendidikan https://jurnal.unibrah.ac.id/index.php/JIWP (2020).

Zulaini, nabila nurbati, Nurul Mufidah, Nur Kholis, and muhammad afifi Amrullah. "Learning Arabic for Elementary Schools During the Covid-19 Outbreak." AlMudarris 3, no. 1 (2020). 